\title{
Water Treatment Coagulation: Dares and Trends
}

\author{
Djamel Ghernaout ${ }^{1,2 *}$ \\ ${ }^{1}$ Chemical Engineering Department, College of Engineering, University of Ha'il, Ha'il, Saudi Arabia \\ ${ }^{2}$ Chemical Engineering Department, Faculty of Engineering, University of Blida, Blida, Algeria \\ Email: ^djamel_andalus@hotmail.com
}

How to cite this paper: Ghernaout, D. (2020) Water Treatment Coagulation: Dares and Trends. Open Access Library Journal, 7: e6636.

https://doi.org/10.4236/oalib.1106636

Received: July 22, 2020

Accepted: August 11, 2020

Published: August 14, 2020

Copyright $\odot 2020$ by author(s) and Open Access Library Inc.

This work is licensed under the Creative Commons Attribution International License (CC BY 4.0).

http://creativecommons.org/licenses/by/4.0/ (c) (i) Open Access

\begin{abstract}
Coagulation remains a technique by which finely dispersed solids are efficiently eliminated. It has been largely expanded and remains the most unavoidable method for treating water. This review focuses on colloid stability, coagulation mechanisms, and coagulant types. It presents electrocoagulation as an option of conventional coagulation and discusses challenges in coagulation technology especially health hazards in used chemicals toxicity. As promising solutions, new developments in terms of using coagulants are presented. Micropollutants are inorganic and organic substances that could disturb negatively nature even at very low levels. Microplastics are also observed. Coagulation could retain different micropollutants and microplastics at varying efficiencies even if there is a need to determine running circumstances that could increase their reduction. As a perspective, coagulation may be combined with additional processes, such as ultrafiltration. Further, traditional water treatment should be deeply revised.
\end{abstract}

\section{Subject Areas}

Chemical Engineering \& Technology

\section{Keywords}

Coagulation, Water Treatment, Dissolved Organic Matter (DOM), Disinfection By-Products (DBPs), Chemicals Toxicity

\section{Introduction}

Coagulation remains a technique by which finely dispersed solids are efficaciously eliminated [1] [2] [3]. Firstly employed by the ancient Egyptians as early as 2000 B.C.E [4] [5] [6], coagulation process has been largely expanded, espe- 
cially during the last century. Nowadays, it remains the most unavoidable method for treating water [7] [8] [9].

Pursued by clarification stages (mostly decantation and (sand) filtration processes), coagulation remains the most performant for retaining particulate matter (it carries both colloids, mostly $10 \mathrm{~nm}$ to $1 \mu \mathrm{m}$, and small particles, usually > $1 \mu \mathrm{m}$ ) from water (Table 1) [10] [11] [12]. Further, it eliminates dissolved portions of some matters such as natural organic matter (NOM, like humic substances) from surface water [7] [13] [14].

This review focuses on colloid stability, coagulation mechanisms, and coagulant types. It presents electrocoagulation as an option of conventional coagulation and discusses challenges in coagulation technology especially health hazards in used chemicals toxicity. As promising solutions, new developments in terms of using coagulants are presented.

\section{Colloid Stability}

In water, colloids are negatively charged [7]. The cations in water, known as counter-ions, are strongly fixed to the colloid's surface and constitute the Stern layer. In addition to such counter-ions, many other positive ions are also pulled to the same colloid, because of their positive charge and the negative charge of the colloid, even if somewhat loosely because of the repulsion from the cations in the Stern layer, as well as because of the competition for attachment by other cations. This leads to a dynamic equilibrium producing the diffuse layer. In such layer, the level of the counter-ions gradually reduces with the distance from the colloid. In water, the anions, as well known as co-ions, gradually augment their occurrence in the diffuse layer, generating an equilibrium. The Stern layer and the diffuse layer constitute the so-named double layer. Such layers are presented in Figure 1.

The identical negative charge of the particles and the width of the double layers avoid agglomeration of particles with each other. This is why the colloids stay dispersed in water until their charges and the double layers are considerably diminished [7].

Table 1. Coagulation terminology [7] [15] [16].

\begin{tabular}{|c|c|}
\hline Term & Description \\
\hline Coagulation & $\begin{array}{l}\text { Coagulation is the phenomenon by which colloids are destabilized, conducting to } \\
\text { their agglomeration [17] [18] [19]. }\end{array}$ \\
\hline $\begin{array}{l}\text { Flocculation, } \\
\text { clarification }\end{array}$ & $\begin{array}{l}\text { Practically, the coagulation technology is composed of coagulation, flocculation and } \\
\text { clarification (separation unit stages) [20] [21] [22]. Following the coagulation, the } \\
\text { destabilized particles and other precipitates produce agglomerates that require } \\
\text { growing further into larger flocs. This stage is named flocculation. The agglomerated } \\
\text { flocs can then be separated utilizing decantation (or flotation) and filtration methods } \\
{[23][24][25] \text {. }}\end{array}$ \\
\hline $\begin{array}{l}\text { Coagulants, } \\
\text { flocculants }\end{array}$ & $\begin{array}{l}\text { Throughout the coagulation and flocculation stages, chemical products are usually } \\
\text { injected; such agents are known as coagulants and flocculants, respectively. }\end{array}$ \\
\hline
\end{tabular}




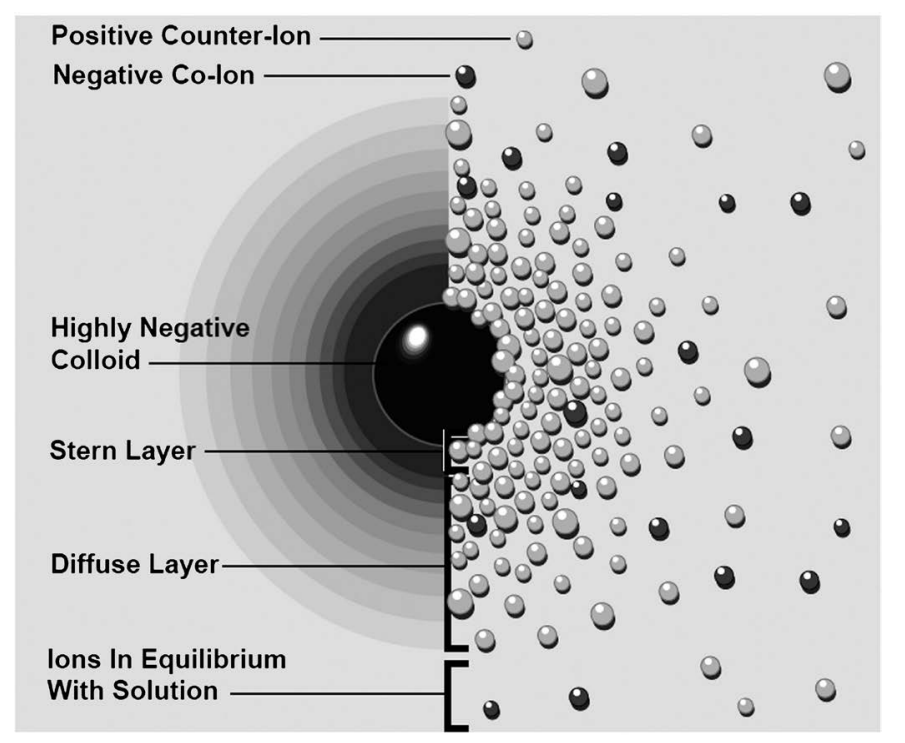

Figure 1. Electrical double layer and distribution of co-ions and counter-ions [26].

The colloid stability is defined by the Derjaguin-Landau-Verwey-Overbeek (DLVO) theory. Such theory proposes that the colloid stability in water is a function of its total potential energy function $V_{T}$, which is the sum of three forces [7]:

$$
V_{T}=V_{A}+V_{R}+V_{S}
$$

where $V_{S}$ is the potential energy attributed to the solvent (water). Practically, it is of minor importance. The attractive force is defined by

$$
V_{A}=-\frac{A}{12 \pi D^{2}}
$$

where $A$ is the Hamaker constant and $D$ is the distance between the particles. $V_{A}$ is also called the van der Waals force [7].

The repulsive force attributed to the electrical double layer is defined by

$$
V_{R}=2 \pi \varepsilon a \xi^{2} e^{-\kappa D}
$$

where $a$ is the particle radius, $\varepsilon$ is the solvent permeability, $\kappa$ is a function of the ionic composition, and $\xi$ is the zeta potential [7].

The energy barrier resulting in the sum of forces (Figure 2) prohibits colloids, which are in Brownian motion, from approaching sufficiently closer where the attraction forces dominate [7].

\section{Coagulation Pathways}

As a rule, there are numerous classifications of coagulation routes encountered in the specialized references. Table 2 lists the four routes including all classifications [7].

Practically, there are two pathways dominant: adsorption-charge neutralization and colloidal entrapment. In addition to these two routes, the double layer compression pathway could affect the coagulation performance with the occurrence of 


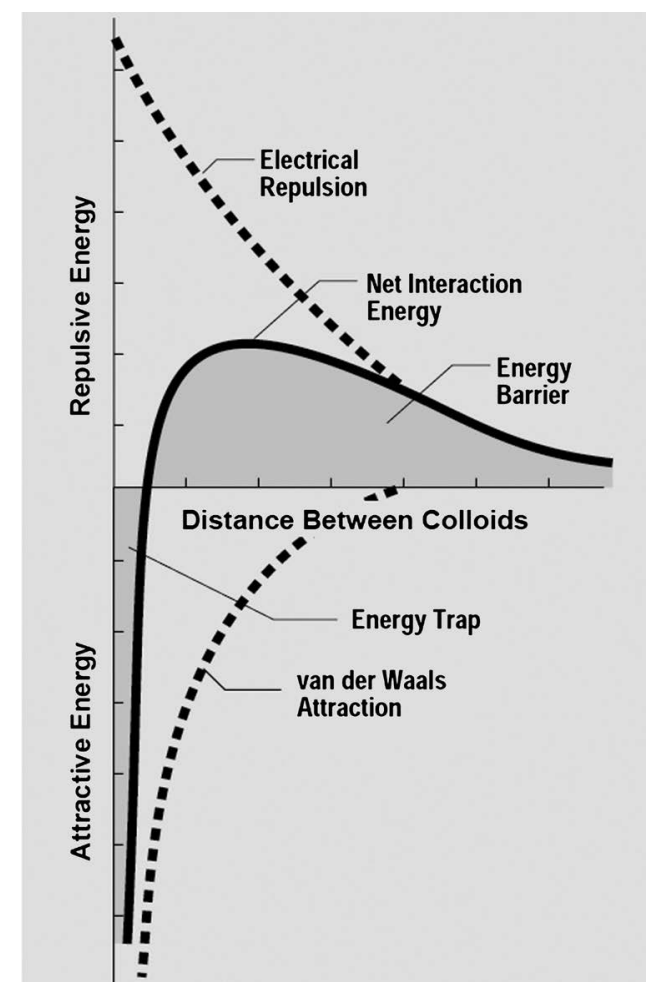

Figure 2. Total potential energy of two particles approaching each other [26].

Table 2. Four coagulation mechanisms [7].

\section{Coagulation mechanism Description}

Mechanism of Particle

Removal

\section{Double Layer Compression}

The compression of the double layer decreases the energy barrier; thus, the colloids can come closer [27] [28] [29]. This is attained via injecting indifferent electrolytes to the water [30] [31] [32]. The Schultz-Hardy rule shows that the impact of the indifferent electrolytes augments with the valence of the ions by sixth exponential power [33] [34] [35]. As an illustration, one mole of $\mathrm{Ca}^{2+}$ possesses the identical impact as $2^{6}$ ions of $\mathrm{Na}^{+}$on the double layer compression [36] [37] [38].

\section{Adsorption-charge neutralization}

In coagulation method, such a mechanism remains the most cost-efficient pathway [39] [40] [41]. During this route, the positively charged ions and species cover the negatively charged colloids, thereby decreasing the surface charge and by that the energy barrier [42] [43] [44]. This mechanism is cost-efficient tanks to the fact that the neutralization process occurs stoichiometrically between the positively and negatively charged ions [45] [46] [47]. Such a pathway could realize coagulation via inorganic coagulants or cationic organic polymers [48] [49] [50].

\section{Interparticle bridging}

Such route takes place when organic coagulants or organic polymers are employed [51] [52] [53]. Polymers possess threads and fibers that bind the particles into big and compact agglomerates [54] [55] [56]. Polymers with higher molecular weight (MW) are frequently more efficacious, thanks to their long chains [57] [58] [59].

Colloidal entrapment or "sweep floc"

The final product of the hydrolysis of inorganic coagulants is the hydroxide precipitates that could entrap colloids [60] [61] [62]. Such pathway consumes coagulants in excess of stoichiometry [63] [64] [65].

Mechanisms of Organic Matter Removal
Natural organic matter (NOM) is the source of natural color in surface waters [66] [67] [68]. NOM removal is fundamental in potable water treatment since it form carcinogenic disinfection by-products (DBPs) [69] [70] [71]. NOM is mostly composed of humic substances (their average size is $0.47-3.3 \mathrm{~nm}$ ) [72] [73] [74]. NOM is quantified by color, ultraviolet (UV) absorption, and total organic carbon [75] [76] [77]. NOM is noted to be retained through all particle removal routes [78] [79] [80]. NOM could dominate coagulant injection and adoption of water treatment technology rather than colloidal particles [81] [82] [83]. 
electrolytes. Colloidal entrapment only happens when inorganic coagulants are injected. The interparticle bridging happens only when organic coagulants are introduced. Table 3 lists the operational dominance of coagulant pathways [7].

\section{Coagulant Types}

\subsection{Mineral Coagulants}

The colloids elimination remains mostly founded on the hydrolysis of mineral coagulants [7]:

$$
\mathrm{Me}^{3+}+3 \mathrm{OH}^{-}=\mathrm{Me}(\mathrm{OH})_{3(\mathrm{~s})}
$$

Reaction (4) takes place during seconds and follows several steps that form numerous intermediate species, which are favorable for coagulation. Following the circumstances, there can be numerous mononuclear hydroxides (like $\mathrm{Al}(\mathrm{OH})^{2+}, \mathrm{Al}(\mathrm{OH})_{2}^{+}, \mathrm{Al}(\mathrm{OH})_{3}$, and $\mathrm{Al}(\mathrm{OH})_{4}^{-}$) or polymerization reactions to polycations (such as $\left.\mathrm{AlO}_{4} \mathrm{Al}_{12}(\mathrm{OH})_{24}\left(\mathrm{OH}_{2}\right)_{12}^{7^{+}}\right)$[7]. More than eighty $\mathrm{Al}$ species can be formed [84]. Figure 3 shows instances of monomers in a solubility diagram and Figure 4 presents the usual pathways related to the coagulants' injection and $\mathrm{pH}$.

Table 3. Practical dominance of the coagulation pathway [7] [63].

\begin{tabular}{ccc}
\hline \multirow{2}{*}{ Mechanism type } & \multicolumn{2}{c}{ Coagulant type } \\
\cline { 2 - 3 } & Inorganic coagulants & Organic coagulants \\
Double layer compression & Occasionally & Not applicable \\
Adsorption-charge neutralization & Dominant & Happens with cationic polymers \\
Interparticle bridging & Not applicable & Dominant \\
Colloidal entrapment (sweep floc) & Occasionally & Not applicable
\end{tabular}

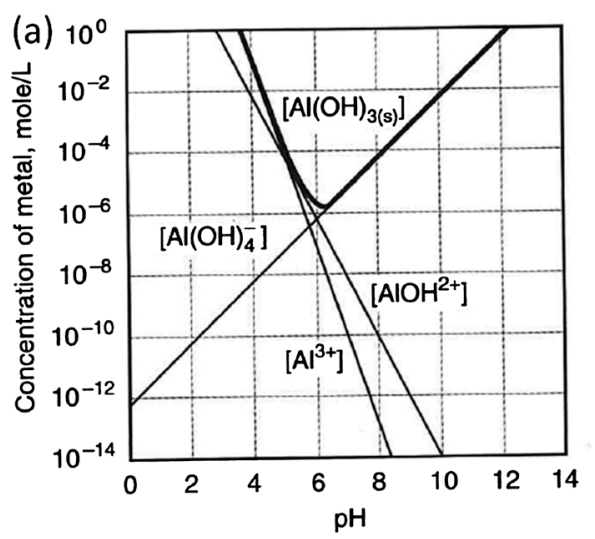

(b)

$$
\begin{aligned}
& \log \left[\mathrm{A}^{3+}\right]=10.8-3 \mathrm{pH} \\
& \log \left[\mathrm{AOOH} \mathrm{H}^{2+}\right]=5.8-2 \mathrm{pH} \\
& \log \left[\mathrm{Al}(\mathrm{OH})_{4}^{-}\right]=-12.2+\mathrm{pH} \\
& \left.\mathrm{C}_{\mathrm{T}}=[\mathrm{A}]^{3+}\right]+\left[\mathrm{AlOH}^{2+}\right]+\left[\mathrm{Al}(\mathrm{OH})_{4}^{-}\right]
\end{aligned}
$$

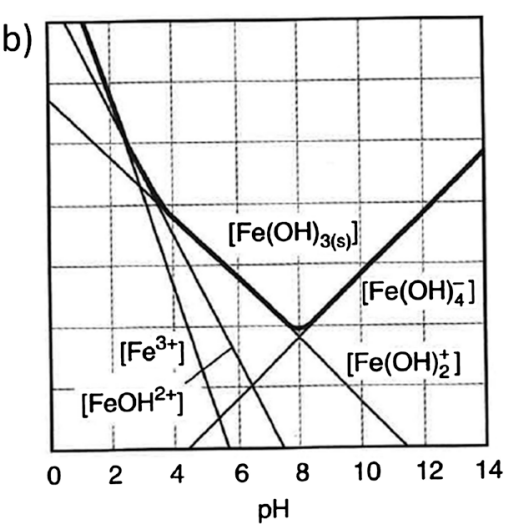

$$
\begin{aligned}
& \log \left[\mathrm{Fe}^{3+}\right]=3.2-3 \mathrm{pH} \\
& \log \left[\mathrm{FeOH}^{2+}\right]=1.0-2 \mathrm{pH} \\
& \log \left[\mathrm{Fe}(\mathrm{OH})_{2}^{+}\right]=-2.5-\mathrm{pH} \\
& \log \left[\mathrm{Fe}(\mathrm{OH})_{4}^{-}\right]=-18.4+\mathrm{pH} \\
& \mathrm{C}_{\mathrm{T}}=\left[\mathrm{Fe}^{3+}\right]+\left[\mathrm{FeOH}{ }^{2+}\right]+\left[\mathrm{Fe}(\mathrm{OH})_{2}^{+}\right]+\left[\mathrm{Fe}(\mathrm{OH})_{4}^{-}\right]
\end{aligned}
$$

Figure 3. Solubility diagrams of (a) $\mathrm{Al}(\mathrm{III})$ and (b) Fe(III), with monomeric species [85]. 

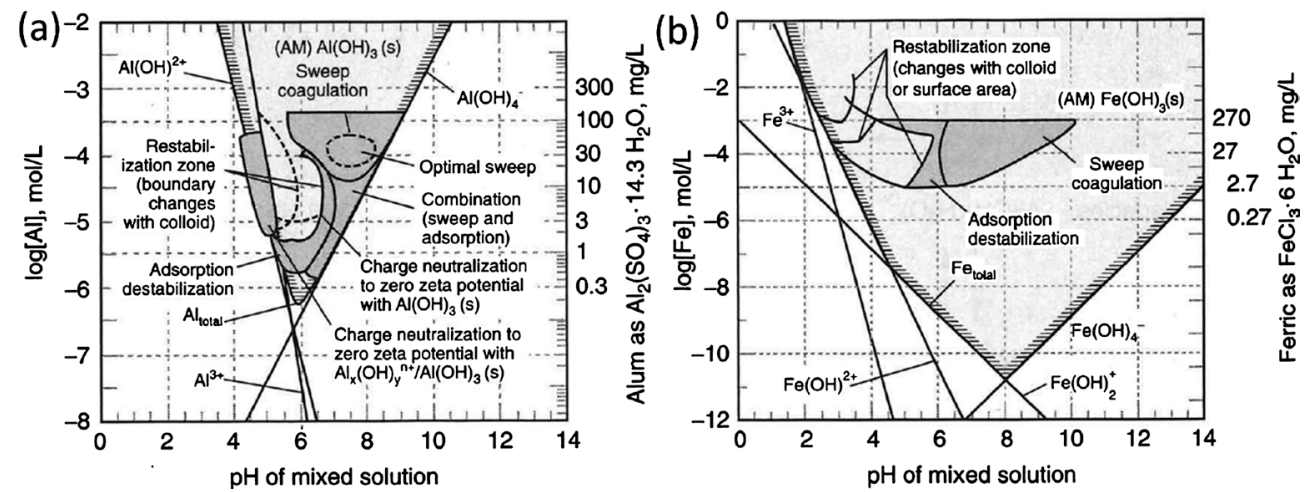

Figure 4. Usual coagulation working diagram. (a) $\mathrm{Al}(\mathrm{III})$ and (b) $\mathrm{Fe}$ (III) [86].

In the water treatment industry, the most frequent coagulants remain aluminum sulfate, ferric chloride, ferric sulfate chloride, and calcium hydroxide. Since the 1980s, investigation has conducted to the formation of pre-polymerized aluminum hydroxychlorides, enabling better utilization of mono- and polynuclear species. For such coagulants, the ratio of $\mathrm{OH} / \mathrm{Al}$ stays a fundamental parameter [7].

Innovative coagulants with combinations of calcium (to augment the double layer impact), water glass (to improve sedimentation properties), flocculants (to avert the request for two injecting systems), and so on are more and more mentioned even if their large usage is restricted [7].

\subsection{Organic Coagulants}

Organic coagulants possess synthetic and biological origins. The synthetic polymers are prevailing as both coagulants and flocculants. The synthetic polymers are mostly polyamines, polydiallyldimethylammonium chloride (poly-DADMACS), dicyandiamide resins, and melamine-formaldehyde resins. The polyacrylamides and poly-DADMACs are likely the most famous cationic coagulants. Such coagulants are known by their MW $(3000-3,000,000)$ and cationic charge density (low to extra high) [7].

Extracted from crab and shrimp shells, chitosans are adopted as performant biological coagulants in potable water industry thanks to their numerous merits. They work over a larger $\mathrm{pH}$ span without changing the $\mathrm{pH}$ of the treated water and they do not generate any remaining aluminum. Nevertheless, their drawback remains the cost, since the organic polymers are considerably more expensive than inorganic coagulants, and biopolymers are even more expensive than synthetic organic polymers [7].

\subsection{Flocculants}

As flocculants, the synthetic organic polymers are utilized. They possess different degrees of anionic, non-ionic, or cationic charge and could have MWs of $3,000,000$ to $20,000,000$. The flocculants could greatly augment the floc production speed and the strength of the flocs and make them much heavier. Floccu- 
lants are efficient products that increase the length of filtration (delayed breakthrough) in drinking water treatment [7] [87].

\section{Coagulation Technique Options}

\subsection{Traditional Potable Water Treatment}

Figure 5 shows traditional potable water. It is frequent to insert sieves or micro-sieves before coagulation and disinfection stages of the final treated water [88] [89] [90]. If the water possesses low $\mathrm{pH} /$ alkalinity, the $\mathrm{pH} /$ alkalinity will be adjusted following the disinfection step [91] [92] [93]. Taking into account the components in between such two steps, a collection of coagulation methods have been adopted [94] [95] [96]. The most usual coagulation techniques are founded on a coagulant mixing zone followed by a flocculation step where the flocs are progressively formed [97] [98] [99]. Following flocculation, the flocs are separated via a decantation or flotation step [100] [101] [102]. It is frequent to insert a filtration step that also comprise a Granular or Powder Activated Carbon (GAC or PAC filter that could reduce any residual organic matters) [103] [104] [105]. If the raw water has low colloids amount, coagulation could happen without decantation or flotation, and the separation of the microflocs takes place indirectly in the filter [106] [107] [108]. If there is a flocculation step or not, the technique integrations are called contact filtration or direct filtration [109] [110] [111]. Keeping the coagulation $\mathrm{pH}$ inside the running spans of the respective coagulants stays fundamental. In numerous conditions, particularly if the raw water source is soft, the coagulants are injected simultaneously with $\mathrm{CO}_{2}$ and lime to control the $\mathrm{pH}$ that also positively participates to dominating corrosion in the distribution system [7] [112] [113].

\subsection{Electrocoagulation (EC) Process}

Employing electrochemical technology, coagulation could also be realized. An electrochemical cell equipped with $\mathrm{Fe}$ or $\mathrm{Al}$ electrodes can generate in situ hydrolysis species, conducting to coagulation like when introducing inorganic salts [114]. Electrocoagulation (EC) presents the simplicity of injecting control via adjusting the electrical current flow across the device. EC is also well known for its disinfection features [115] [116]. EC is largely employed in industrial wastewater treatment and its large application in the water supply and urban wastewater treatment remains to be implemented [7] [117] [118].

\section{Dares in Water Coagulation}

\subsection{Health Risks in Water Coagulation}

As previously mentioned, coagulation stays the most usual technique in dealing with water treatment and $\mathrm{Al}$ salts are the most widely used coagulants. $\mathrm{Al}$ species are detected in dissolved forms beyond $\mathrm{pH}$ ranges relevant to their levels (Figure 3 and Figure 4). Non-optimal injection of coagulants, particularly in water with 
Conventional water treatment process without filtration

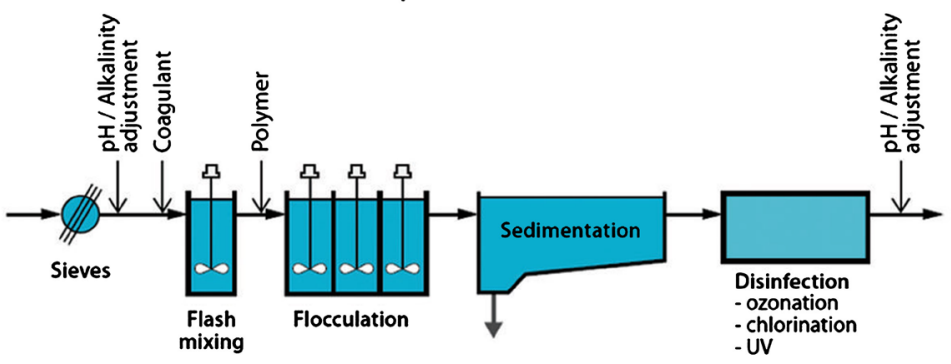

Conventional water treatment process

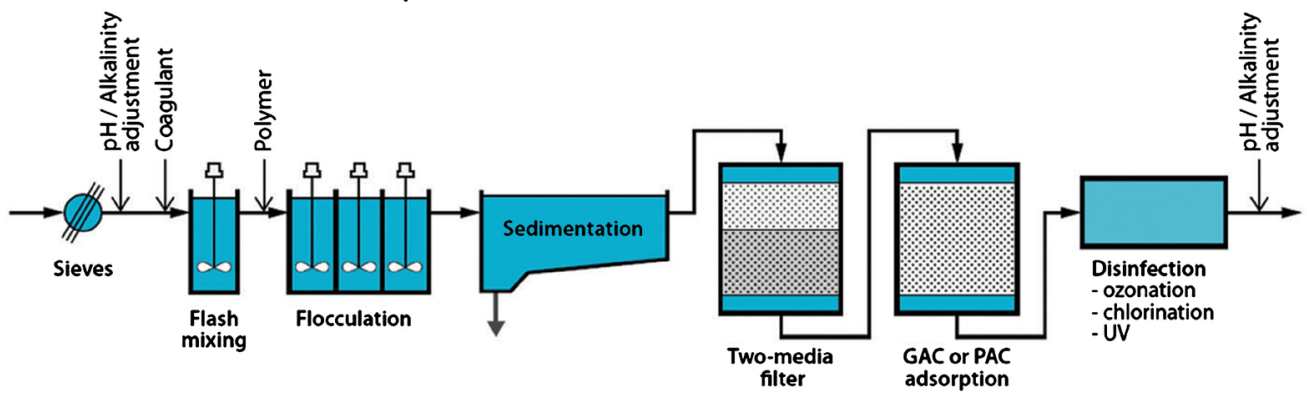

Water treatment process with flotation

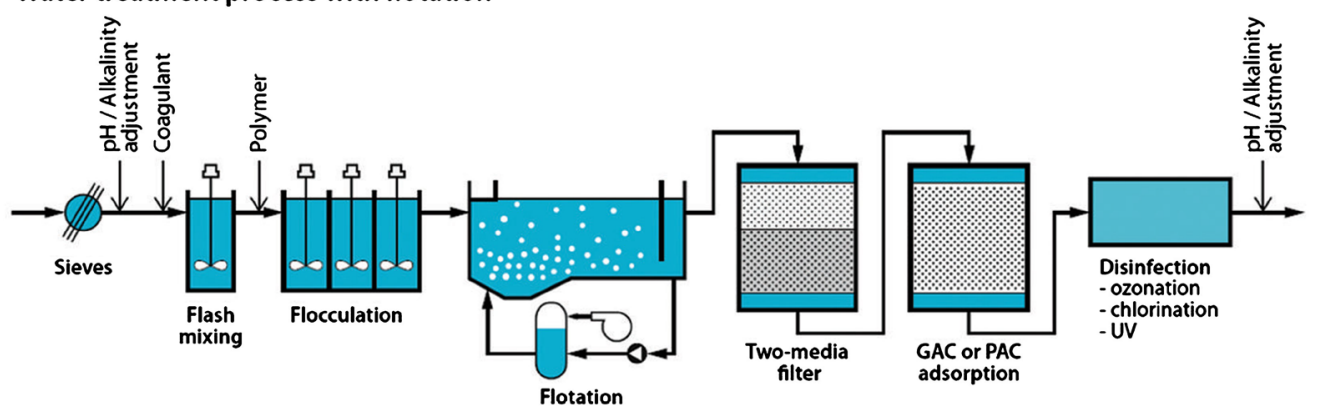

Direct filtration process

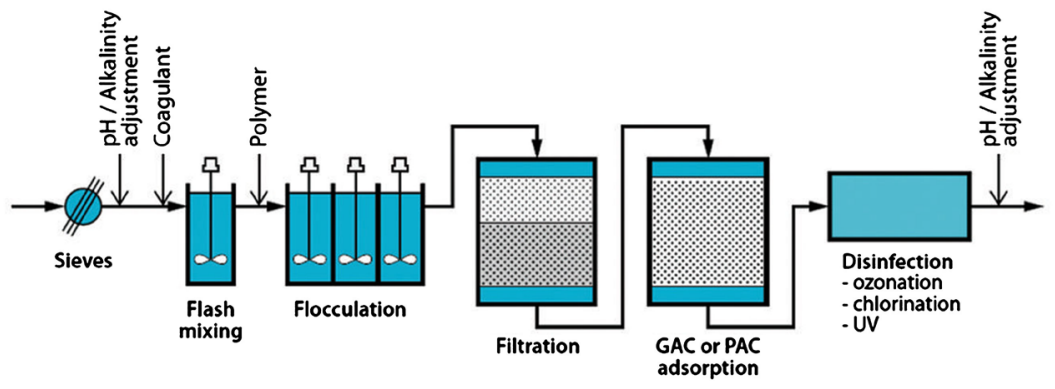

Contact filtration

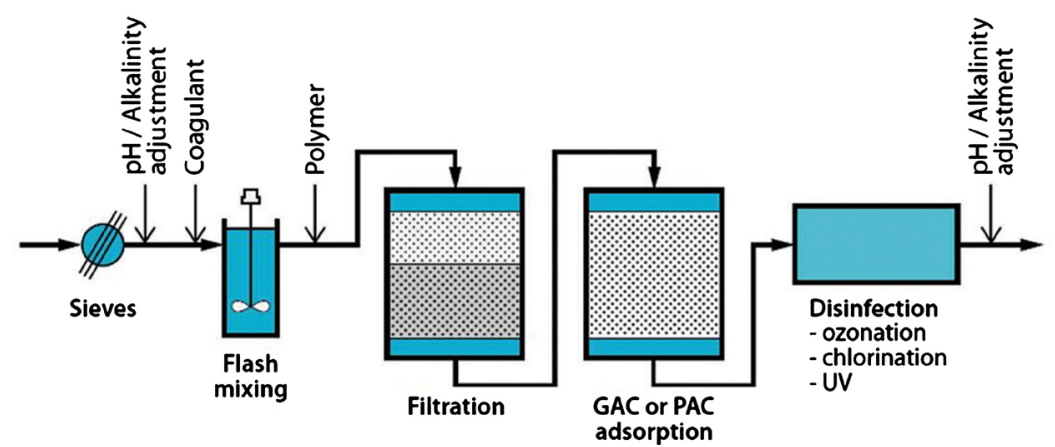

Figure 5. Coagulation method options in potable water treatment industry [7]. 
low alkalinity, could modify the coagulation $\mathrm{pH}$ to unwanted ranges where some of the aluminum will be in dissolved form. The usual separation techniques are unable to retain dissolved portions, and they may end up in the supplies to the consumers [119]. There are shreds of evidence of a linkage between the aluminum concentrations in drinking water and Alzheimer's disease. Employing Fe-based coagulants may avert this hazard, usually with favorable effects on denser flocs, conducting to better sedimentation features [7].

In water supply systems, the excessive Al levels could be efficaciously controlled via fixing optimal coagulant injections to aver over- and under-dosages integrated with overriding with coagulation $\mathrm{pH}$ range control to secure favorable $\mathrm{pH}$ ranges. A different strategy is to employ biopolymers (like chitosan), even if their usage is not yet economically feasible in bigger treatment facilities [7].

\subsection{Over- and Under-Dosage Conducting to Disinfection By-Products (DBPs)}

Many treatment plants prefer to employ raw water from lakes rather than from rivers, because of its more stable water qualities [7]. The drawback is that some lake waters mostly carry out an elevated level of NOM that produce carcinogenic compounds (e.g., trihalomethanes) during chlorination. Therefore, NOM should be reduced prior to chlorination. Nevertheless, the non-optimal coagulant dosing and unfavorable $\mathrm{pH}$ ranges could lead to poor reduction of NOM, conducting to health dangers. The dare has augmented lately with the augmentation of NOM levels in lake water because of climate change.

As a possible option, utilizing more optimal dosing control systems, which rapidly respond to variations in raw water quality and maintain favorable $\mathrm{pH}$ ranges, is suggested [7].

\section{New Developments as Potential Options in Terms of Using Coagulants}

There are recent enhancements in terms of utilizing coagulants. As a rule, $\mathrm{Ca}^{2+}$, $\mathrm{Fe}^{3+}$, and $\mathrm{Al}^{3+}$ salts have been utilized as coagulants. Even if $\mathrm{Ca}^{2+}$ salts have become less frequent, $\mathrm{Al}^{3+}$ has become the dominant coagulant in the water treatment industry. In order to elevate the performance of such classical chemicals, pre-polymerized coagulants were suggested four decades ago. They are synthetized via carrying out partial hydrolysis, enabling more efficacious use of positively charged hydrolysis species (mostly in an adsorption-charge-neutralization mechanism). Whilst the first generation of pre-polymerized coagulants was polyaluminum chlorides and polyferric chlorides, a recent generation of coagulants like polyaluminum silicate sulfate, polyferric sulfate, and polyaluminum ferric sulfates are well examined. Prepolymerized coagulants possess numerous merits over conventional aluminum sulfate (alum) [7].

Lately, $\mathrm{Ti}^{4+}$ and $\mathrm{Zr}^{4+}$ salts have been suggested as highly efficient coagulants, considering their high valence. Nevertheless, they are not yet employed at large scales, mostly because of their elevated prices [7]. 


\section{Conclusions}

This review focused on colloid stability, coagulation mechanisms, and coagulant types. It presented EC as an option of conventional coagulation and discussed challenges in coagulation technology especially health hazards in used chemicals toxicity. As promising solutions, new developments in terms of using coagulants are presented. The main findings of this work are listed below:

Micropollutants are inorganic and organic substances that could disturb negatively nature even at very low levels. Heavy metals are traditionally known as micropollutants. Organic micropollutants comprise both classical (dichlorodiphenyltrichloro-ethane, polychlorinated biphenyls, polycyclic aromatic hydrocarbons, pesticides) and emerging contaminants (hormones, endocrine disruptors, pharmaceuticals, and personal care products). The traditional water treatment techniques are frequently not concentrating on the reduction of such matters. Nevertheless, there is a request to eliminate them during water treatment. Coagulation could retain different micropollutants at 6\% - 90\% [120]; however, there is still a necessity to determine running circumstances that could increase the reduction of micropollutants.

In potable water resources, microplastics are observed. Microplastics generate a hazard to human health and nature. For their elimination, coagulation could be efficaciously employed. Combining coagulation with, for instance, ultrafiltration, has illustrated great capacity for their elimination from water.

\section{Acknowledgements}

The Research Deanship of University of Ha'il, Saudi Arabia, through the Project RG-191190, has funded this research.

\section{Conflicts of Interest}

The author declares no conflicts of interest regarding the publication of this paper.

\section{References}

[1] Ghernaout, D., Ghernaout, B. and Kellil, A. (2009) Natural Organic Matter Removal and Enhanced Coagulation as a Link between Coagulation and Electrocoagulation. Desalination and Water Treatment, 2, 203-222.

https://doi.org/10.5004/dwt.2009.116

[2] Ghernaout, B., Ghernaout, D. and Saiba, A. (2010) Algae and Cyanotoxins Removal by Coagulation/Flocculation: A Review. Desalination and Water Treatment, 20, 133-143. https://doi.org/10.5004/dwt.2010.1202

[3] Ghernaout, D., Naceur, M.W. and Ghernaout, B. (2011) A Review of Electrocoagulation as a Promising Coagulation Process for Improved Organic and Inorganic Matters Removal by Electrophoresis and Electroflotation. Desalination and Water Treatment, 28, 287-320. https://doi.org/10.5004/dwt.2011.1493

[4] Ghernaout, D. (2014) The Hydrophilic/Hydrophobic Ratio vs. Dissolved Organics Removal by Coagulation-A Review. Journal of King Saud University-Science, 26, 169-180. https://doi.org/10.1016/j.jksus.2013.09.005 
[5] Ghernaout, D., Moulay, S., Ait Messaoudene, N., Aichouni, M., Naceur, M.W. and Boucherit, A. (2014) Coagulation and Chlorination of NOM and Algae in Water Treatment: A Review. International Journal of Environmental Monitoring and Analysis, 2, 23-34. https://doi.org/10.11648/j.ijema.s.2014020601.14

[6] Ghernaout, D. (2008) Élimination des substances humiques et des germes indicateurs de contamination bactériologique par électrocoagulation assistée d'un traitement magnétique de l'eau. Ph.D. Thesis, University of Blida, Algeria.

[7] Ratnaweera, H. (2020) Meeting Tomorrow's Challenges in Particle Separation with Coagulation. In: Chernyshova, I., Ponnurangam, S. and Liu, Q., Eds., Multidisciplinary Advances in Efficient Separation Processes, ACS Symposium Series 1348, American Chemical Society, Washington DC, 207-223.

https://doi.org/10.1021/bk-2020-1348.ch007

[8] Ghernaout, D., Al-Ghonamy, A.I., Boucherit, A., Ghernaout, B., Naceur, M.W., Ait Messaoudene, N., Aichouni, M., Mahjoubi, A.A. and Elboughdiri, N.A. (2015) Brownian Motion and Coagulation Process. American Journal of Environmental Protection, 4, 1-15.

[9] Ghernaout, D., Al-Ghonamy, A.I., Naceur, M.W., Boucherit, A., Messaoudene, N. A., Aichouni, M., Mahjoubi, A.A. and Elboughdiri, N.A. (2015) Controlling Coagulation Process: From Zeta Potential to Streaming Potential. American Journal of Environmental Protection, 4, 16-27. https://doi.org/10.11648/j.ajeps.s.2015040501.12

[10] Ghernaout, D. and Boucherit, A. (2015) Review of Coagulation's Rapid Mixing for NOM Removal. Journal of Research \& Developments in Chemistry, 2015, Article ID: 926518. https://doi.org/10.5171/2015.926518

[11] Ghernaout, D., Badis, A., Braikia, G., Matâam, N., Fekhar, M., Ghernaout, B. and Boucherit, A. (2017) Enhanced Coagulation for Algae Removal in a Typical Algeria Water Treatment Plant. Environmental Engineering and Management Journal, 16, 2303-2315. https://doi.org/10.30638/eemj.2017.238

[12] Ghernaout, D. (2017) Entropy in the Brownian Motion (BM) and Coagulation Background. Colloid and Surface Science, 2, 143-161.

[13] Ghernaout, D., Simoussa, A., Alghamdi, A., Ghernaout, B., Elboughdiri, N., Mahjoubi, A., Aichouni, M. and El-Wakil, A.E.A. (2018) Combining Lime Softening with Alum Coagulation for Hard Ghrib Dam Water Conventional Treatment. International Journal of Advanced and Applied Sciences, 5, 61-70.

https://doi.org/10.21833/ijaas.2018.05.008

[14] Djezzar, S., Ghernaout, D., Cherifi, H., Alghamdi, A., Ghernaout, B. and Aichouni, M. (2018) Conventional, Enhanced, and Alkaline Coagulation for Hard Ghrib Dam (Algeria) Water. World Journal of Applied Chemistry, 3, 41-55. https://doi.org/10.11648/j.wjac.20180302.12

[15] Kellali, Y. and Ghernaout, D. (2019) Physicochemical and Algal Study of Three Dams (Algeria) and Removal of Microalgae by Enhanced Coagulation. Applied Engineering, 3, 56-64.

[16] Ghernaout, D., Elboughdiri, N., Ghareba, S. and Salih, A. (2020) Coagulation Process for Removing Algae and Algal Organic Matter-An Overview. Open Access Library Journal, 7, e6272. https://doi.org/10.4236/oalib.1106272

[17] Ghernaout, D. (2020) Enhanced Coagulation: Promising Findings and Challenges. Open Access Library Journal, 7, e6569. https://doi.org/10.4236/oalib.1106569

[18] Ghernaout, D. (2019) Disinfection via Electrocoagulation Process: Implied Mechanisms and Future Tendencies. EC Microbiology, 15, 79-90. 
[19] Ghernaout, D. and Elboughdiri, N. (2020) Electrocoagulation Process in the Context of Disinfection Mechanism. Open Access Library Journal, 7, e6083.

[20] Ghernaout, D. and Elboughdiri, N. (2020) An Insight in Electrocoagulation Process through Current Density Distribution (CDD). Open Access Library Journal, 7, e6142.

[21] Ghernaout, D. and Ghernaout, B. (2010) From Chemical Disinfection to Electrodisinfection: The Obligatory Itinerary? Desalination and Water Treatment, 16, 156-175. https://doi.org/10.5004/dwt.2010.1085

[22] Ghernaout, D. Benblidia, C. and Khemici, F. (2015) Microalgae Removal from Ghrib Dam (Ain Defla, Algeria) Water by Electroflotation Using Stainless Steel Electrodes. Desalination and Water Treatment, 54, 3328-3337. https://doi.org/10.1080/19443994.2014.907749

[23] Ghernaout, D., El-Wakil, A., Alghamdi, A., Elboughdiri, N. and Mahjoubi, A. (2018) Membrane Post-Synthesis Modifications and How It Came about. International Journal of Advanced and Applied Sciences, 5, 60-64. https://doi.org/10.21833/ijaas.2018.02.010

[24] Ghernaout, D. and El-Wakil, A. (2017) Requiring Reverse Osmosis Membranes Modifications-An Overview. American Journal of Chemical Engineering, 5, 81-88. https://doi.org/10.11648/j.ajche.20170504.15

[25] Ghernaout, D. (2017) Reverse Osmosis Process Membranes Modeling-A Historical Overview. Journal of Civil, Construction and Environmental Engineering, 2, 112-122.

[26] Zeta-Meter Inc. Zeta Potential: A Complete Course in 5 Minutes. http://www.zeta-meter.com/5min.pdf

[27] Ghernaout, D. (2013) The Best Available Technology of Water/Wastewater Treatment and Seawater Desalination: Simulation of the Open Sky Seawater Distillation. Green and Sustainable Chemistry, 3, 68-88.

[28] Ghernaout, D. (2017) Water Treatment Chlorination: An Updated Mechanistic Insight Review. Chemistry Research Journal, 2, 125-138.

[29] Ghernaout, D. (2018) Magnetic Field Generation in the Water Treatment Perspectives: An Overview. International Journal of Advances in Applied Sciences, 5, 193-203. https://doi.org/10.21833/ijaas.2018.01.025

[30] Ghernaout, D. (2018) Disinfection and DBPs Removal in Drinking Water Treatment: A Perspective for a Green Technology. International Journal of Advances in Applied Sciences, 5, 108-117. https://doi.org/10.21833/ijaas.2018.02.018

[31] Ghernaout, D., Aichouni, M. and Alghamdi, A. (2018) Applying Big Data (BD) in Water Treatment Industry: A New Era of Advance. International Journal of Advances in Applied Sciences, 5, 89-97. https://doi.org/10.21833/ijaas.2018.03.013

[32] Ghernaout, D., Alshammari, Y. and Alghamdi, A. (2018) Improving Energetically Operational Procedures in Wastewater Treatment Plants. International Journal of Advances in Applied Sciences, 5, 64-72. https://doi.org/10.21833/ijaas.2018.09.010

[33] Al Arni, S., Amous, J. and Ghernaout, D. (2019) On the Perspective of Applying of a New Method for Wastewater Treatment Technology: Modification of the Third Traditional Stage with Two Units, One by Cultivating Microalgae and Another by Solar Vaporization. International Journal of Environmental Sciences \& Natural Resources, 16, Article ID: 555934. https://doi.org/10.19080/IJESNR.2019.16.555934

[34] Alshammari, Y., Ghernaout, D., Aichouni, M. and Touahmia, M. (2018) Improving Operational Procedures in Riyadh's (Saudi Arabia) Water Treatment Plants Using Quality Tools. Applied Engineering, 2, 60-71. 
[35] Ghernaout, D. (2019) Reviviscence of Biological Wastewater Treatment-A Review. Applied Engineering, 3, 46-55.

[36] Ghernaout, D. (2019) Greening Cold Fusion as an Energy Source for Water Treatment Distillation-A Perspective. American Journal of Quantum Chemistry and Molecular Spectroscopy, 3, 1-5.

[37] Ghernaout, D. and Elboughdiri, N. (2019) Upgrading Wastewater Treatment Plant to Obtain Drinking Water. Open Access Library Journal, 6, e5959. https://doi.org/10.4236/oalib.1105959

[38] Ghernaout, D. and Elboughdiri, N. (2020) Electrochemical Technology for Wastewater Treatment: Dares and Trends. Open Access Library Journal, 7, e6020.

[39] Ghernaout, D., Elboughdiri, N. and Ghareba, S. (2020) Fenton Technology for Wastewater Treatment: Dares and Trends, Open Access Library Journal, 7, e6045. https://doi.org/10.4236/oalib.1106045

[40] Ghernaout, D. and Elboughdiri, N. (2020) Advanced Oxidation Processes for Wastewater Treatment: Facts and Future Trends. Open Access Library Journal, 7, e6139. https://doi.org/10.4236/oalib.1106139

[41] Ghernaout, D. and Elboughdiri, N. (2020) Domestic Wastewater Treatment: Difficulties and Reasons, and Prospective Solutions-China as an Example. Open Access Library Journal, 7, e6141.

[42] Ghernaout, D. (2020) Water Treatment Challenges towards Viruses Removal. Open Access Library Journal, 7, e6408.

[43] Ghernaout, D., Badis, A., Ghernaout, B. and Kellil, A. (2008) Application of Electrocoagulation in Escherichia coli Culture and Two Surface Waters. Desalination, 219, 118-125. https://doi.org/10.1016/j.desal.2007.05.010

[44] Ghernaout, D., Ghernaout, B. and Boucherit, A. (2008) Effect of pH on Electrocoagulation of Bentonite Suspensions in Batch Using Iron Electrodes. Journal of Dispersion Science and Technology, 29, 1272-1275. https://doi.org/10.1080/01932690701857483

[45] Saiba, A., Kourdali, S., Ghernaout, B. and Ghernaout, D. (2010) In Desalination, from 1987 to 2009, the Birth of a New Seawater Pretreatment Process: Electrocoagulation-An Overview. Desalination and Water Treatment, 16, 201-217. https://doi.org/10.5004/dwt.2010.1094

[46] Belhout, D., Ghernaout, D., Djezzar-Douakh, S. and Kellil, A. (2010) Electrocoagulation of a Raw Water of Ghrib Dam (Algeria) in Batch Using Iron Electrodes. Desalination and Water Treatment, 16, 1-9. https://doi.org/10.5004/dwt.2010.1081

[47] Ghernaout, D. and Ghernaout, B. (2011) On the Controversial Effect of Sodium Sulphate as Supporting Electrolyte on Electrocoagulation Process: A Review. Desalination and Water Treatment, 27, 243-254. https://doi.org/10.5004/dwt.2011.1983

[48] Ghernaout, D. (2013) Advanced Oxidation Phenomena in Electrocoagulation Process: A Myth or a Reality? Desalination and Water Treatment, 51, 7536-7554. https://doi.org/10.1080/19443994.2013.792520

[49] Ghernaout, D., Al-Ghonamy, A.I., Naceur, M.W., Ait Messaoudene, N. and Aichouni, M. (2014) Influence of Operating Parameters on Electrocoagulation of C.I. Disperse Yellow 3. Journal of Electrochemical Science and Engineering, 4, 271-283. https://doi.org/10.5599/jese.2014.0065

[50] Ghernaout, D., Al-Ghonamy, A.I., Irki, S., Grini, A., Naceur, M.W. and Aichouni, M. (2014) Decolourization of Bromophenol Blue by Electrocoagulation Process. Trends in Chemical Engineering, 15, 29-39. 
[51] Ghernaout, D., Al-Ghonamy, A.I., Ait Messaoudene, N., Aichouni, M., Naceur, M.W., Benchelighem, F.Z. and Boucherit, A. (2015) Electrocoagulation of Direct Brown 2 (DB) and BF Cibacete Blue (CB) Using Aluminum Electrodes. Separation Science and Technology, 50, 1413-1420.

https://doi.org/10.1080/01496395.2014.982763

[52] Irki, S., Ghernaout, D. and Naceur, M.W. (2017) Decolourization of Methyl Orange (MO) by Electrocoagulation (EC) Using Iron Electrodes under a Magnetic Field (MF). Desalination and Water Treatment, 79, 368-377. https://doi.org/10.5004/dwt.2017.20797

[53] Ghernaout, D. (2018) Electrocoagulation Process: Achievements and Green Perspectives. Colloid and Surface Science, 3, 1-5. https://doi.org/10.11648/j.css.20180301.11

[54] Irki, S., Ghernaout, D., Naceur, M.W., Alghamdi, A. and Aichouni, M. (2018) Decolorization of Methyl Orange (MO) by Electrocoagulation (EC) Using Iron Electrodes under a Magnetic Field (MF). II. Effect of Connection Mode. World Journal of Applied Chemistry, 3, 56-64. https://doi.org/10.11648/j.wjac.20180302.13

[55] Irki, S., Ghernaout, D., Naceur, M.W., Alghamdi, A. and Aichouni, M. (2018) Decolorizing Methyl Orange by Fe-Electrocoagulation Process-A Mechanistic Insight. International Journal of Environmental Chemistry, 2, 18-28.

https://doi.org/10.11648/j.ijec.20180201.14

[56] Ghernaout, D. Touahmia, M. and Aichouni, M. (2019) Disinfecting Water: Electrocoagulation as an Efficient Process. Applied Engineering, 3, 1-12.

[57] Ghernaout, D., Aichouni, M. and Touahmia, M. (2019) Mechanistic Insight into Disinfection by Electrocoagulation-A Review. Desalination and Water Treatment, 141, 68-81. https://doi.org/10.5004/dwt.2019.23457

[58] Ghernaout, D., Alghamdi, A. and Ghernaout, B. (2019) Electrocoagulation Process: A Mechanistic Review at the Dawn of Its Modeling. Journal of Environmental Science and Allied Research, 2, 51-67. https://doi.org/10.29199/2637-7063/ESAR-201019

[59] Ghernaout, D. (2019) Greening Electrocoagulation Process for Disinfecting Water. Applied Engineering, 3, 27-31.

[60] Ghernaout, D. (2019) Electrocoagulation Process for Microalgal Biotechnology-A Review. Applied Engineering, 3, 85-94.

[61] Ghernaout, D. (2019) Virus Removal by Electrocoagulation and Electrooxidation: New Findings and Future Trends. Journal of Environmental Science and Allied Research, 2019, 85-90. https://doi.org/10.29199/2637-7063/ESAR-202024

[62] Ghernaout, D. (2019) Electrocoagulation and Electrooxidation for Disinfecting Water: New Breakthroughs and Implied Mechanisms. Applied Engineering, 3, 125-133.

[63] Ghernaout, D. and Ghernaout, B. (2012) Sweep Flocculation as a Second Form of Charge Neutralisation -A Review. Desalination and Water Treatment, 44, 15-28. https://doi.org/10.1080/19443994.2012.691699

[64] Ghernaout, D. and Elboughdiri, N. (2019) Electrocoagulation Process Intensification for Disinfecting Water-A Review. Applied Engineering, 3, 140-147.

[65] Ghernaout, D. and Elboughdiri, N. (2019) Iron Electrocoagulation Process for Disinfecting Water-A Review. Applied Engineering, 3, 154-158.

[66] Ghernaout, D., Irki, S. and Boucherit, A. (2014) Removal of $\mathrm{Cu}^{2+}$ and $\mathrm{Cd}^{2+}$, and Humic Acid and Phenol by Electrocoagulation Using Iron Electrodes. Desalination and Water Treatment, 52, 3256-3270.

https://doi.org/10.1080/19443994.2013.852484 
[67] Ghernaout, D. and Elboughdiri, N. (2020) Eliminating Cyanobacteria and Controlling Algal Organic Matter-Short Notes. Open Access Library Journal, 7, e6252. https://doi.org/10.4236/oalib.1106252

[68] Ghernaout, D. and Ghernaout, B. (2012) On the Concept of the Future Drinking Water Treatment Plant: Algae Harvesting From the Algal Biomass for Biodiesel Production-A Review. Desalination and Water Treatment, 49, 1-18. https://doi.org/10.1080/19443994.2012.708191

[69] Boucherit, A., Moulay, S., Ghernaout, D., Al-Ghonamy, A.I., Ghernaout, B., Naceur, M.W., Ait Messaoudene, N., Aichouni, M., Mahjoubi, A.A. and Elboughdiri, N.A (2015) New Trends in Disinfection By-Products Formation upon Water Treatment. Journal of Research \& Developments in Chemistry, 2015, Article ID: 628833.

[70] Ghernaout, D. and Elboughdiri, N. (2020) Strategies for Reducing Disinfection By-Products Formation during Electrocoagulation. Open Access Library Journal, 7, e6076. https://doi.org/10.4236/oalib.1106076

[71] Ghernaout, D. and Elboughdiri, N. (2020) Disinfection By-Products: Presence and Elimination in Drinking Water. Open Access Library Journal, 7, e6140. https://doi.org/10.4236/oalib.1106140

[72] Ghernaout, D., Ghernaout, B., Saiba, A., Boucherit, A. and Kellil, A. (2009) Removal of Humic Acids by Continuous Electromagnetic Treatment Followed by Electrocoagulation in Batch Using Aluminium Electrodes. Desalination, 239, 295-308. https://doi.org/10.1016/j.desal.2008.04.001

[73] Ghernaout, D., Ghernaout, B., Boucherit, A., Naceur, M.W., Khelifa, A. and Kellil, A. (2009) Study on Mechanism of Electrocoagulation with Iron Electrodes in Idealised Conditions and Electrocoagulation of Humic Acids Solution in Batch Using Aluminium Electrodes. Desalination and Water Treatment, 8, 91-99.

https://doi.org/10.5004/dwt.2009.668

[74] Ghernaout, D., Mariche, A., Ghernaout, B. and Kellil, A. (2010) Electromagnetic Treatment-Bi-Electrocoagulation of Humic Acid in Continuous Mode Using Response Surface Method for Its Optimization and Application on Two Surface Waters. Desalination and Water Treatment, 22, 311-329. https://doi.org/10.5004/dwt.2010.1120

[75] Ghernaout, D. and Elboughdiri, N. (2020) Controlling Disinfection By-Products Formation in Rainwater: Technologies and Trends. Open Access Library Journal, 7, e6162. https://doi.org/10.4236/oalib.1106162

[76] Ghernaout, D., Elboughdiri, N., Alghamdi, A. and Ghernaout, B. (2020) Trends in Decreasing Disinfection By-Products Formation during Electrochemical Technologies, Open Access Library Journal, 7, e6337. https://doi.org/10.4236/oalib.1106337

[77] Ghernaout, D. and Elboughdiri, N. (2020) Foresight Look on the Disinfection By-Products Formation. Open Access Library Journal, 7, e6349. https://doi.org/10.4236/oalib.1106349

[78] Ghernaout, D. and Elboughdiri, N. (2020) Disinfection By-Products Regulation: Zero ng/L Target. Open Access Library Journal, 7, e6382.

https://doi.org/10.4236/oalib.1106382

[79] Ghernaout, D. and Elboughdiri, N. (2020) Disinfection By-Products (DBPs) Control Strategies in Electrodisinfection. Open Access Library Journal, 7, e6396. https://doi.org/10.4236/oalib.1106396

[80] Ghernaout, D., Naceur, M.W. and Aouabed, A. (2011) On the Dependence of Chlorine By-Products Generated Species Formation of the Electrode Material and Applied Charge during Electrochemical Water Treatment. Desalination, 270, 9-22. https://doi.org/10.1016/j.desal.2011.01.010 
[81] Edzwald, J. (1993) Coagulation in Drinking Water Treatment: Particles, Organics and Coagulants. Water Science and Technology, 27, 21-35. https://doi.org/10.2166/wst.1993.0261

[82] Ghernaout, D., Ghernaout, B. and Naceur, M.W. (2011) Embodying the Chemical Water Treatment in the Green Chemistry-A Review. Desalination, 271, 1-10. https://doi.org/10.1016/j.desal.2011.01.032

[83] Ghernaout, D. and Naceur, M.W. (2011) Ferrate (VI): In Situ Generation and Water Treatment-A Review. Desalination and Water Treatment, 30, 319-332. https://doi.org/10.5004/dwt.2011.2217

[84] Saukkoriipi, J. (2010) Theoretical Study of the Hydrolysis of Aluminium Complexes. Ph.D. Thesis, University of Oulu, Oulu, Finland.

[85] Tchobanoglous, G., Stensel, H., Tsuchihashi, R. and Burton, F. (2013) Wastewater Engineering: Treatment and Resource Recovery. McGraw-Hill Education, New York.

[86] Crittenden, J., Trussell, R., Hand, D., Howe, K. and Tchobanoglous, G. (2012) MWH's Water Treatment: Principles and Design. 3rd Edition, John Wiley \& Sons, Inc., New York. https://doi.org/10.1002/9781118131473

[87] Ait Messaoudene, N., Naceur, M.W., Ghernaout, D., Alghamdi, A. and Aichouni, M. (2018) On the Validation Perspectives of the Proposed Novel Dimensionless Fouling Index. International Journal of Advances in Applied Sciences, 5, 116-122. https://doi.org/10.21833/ijaas.2018.07.014

[88] Ghernaout, D. (2017) Environmental Principles in the Holy Koran and the Sayings of the Prophet Muhammad. American Journal of Environmental Protection, 6, 75-79. https://doi.org/10.11648/j.ajep.20170603.13

[89] Ghernaout, D. (2017) Microorganisms' Electrochemical Disinfection Phenomena. EC Microbiology, 9, 160-169.

[90] Ghernaout, D. (2018) Increasing Trends towards Drinking Water Reclamation from Treated Wastewater. World Journal of Applied Chemistry, 3, 1-9. https://doi.org/10.11648/j.wjac.20180301.11

[91] Ghernaout, D. (2017) Water Reuse (WR): The Ultimate and Vital Solution for Water Supply Issues. International Journal of Sustainable Development Research, 3, 36-46. https://doi.org/10.11648/j.ijsdr.20170304.12

[92] Ghernaout, D. and Alshammari, Y., Alghamdi, A., Aichouni, M., Touahmia, M. and Ait Messaoudene, N. (2018) Water Reuse: Extenuating Membrane Fouling in Membrane Processes. American Journal of Chemical Engineering, 2, 25-36. https://doi.org/10.11648/j.ajche.20180602.12

[93] Ghernaout, D., Laribi, C., Alghamdi, A., Ghernaout, B., Ait Messaoudene, N. and Aichouni, M. (2018) Decolorization of BF Cibacete Blue (CB) and Red Solophenyle 3BL (RS) Using Aluminum Sulfate and Ferric Chloride. World Journal of Applied Chemistry, 3, 32-40. https://doi.org/10.11648/j.wjac.20180302.11

[94] Ghernaout, D., Alghamdi, A., Aichouni, M. and Touahmia, M. (2018) The Lethal Water Tri-Therapy: Chlorine, Alum, and Polyelectrolyte. World Journal of Applied Chemistry, 3, 65-71. https://doi.org/10.11648/j.wjac.20180302.14

[95] Ghernaout, D. Alghamdi, A. and Ghernaout, B. (2019) Microorganisms' Killing: Chemical Disinfection vs. Electrodisinfection. Applied Engineering, 3, 13-19.

[96] Ghernaout, D. (2019) Aeration Process for Removing Radon from Drinking Water-A Review. Applied Engineering, 3, 32-45.

[97] Ghernaout, D. (2019) Brine Recycling: Towards Membrane Processes as the Best Available Technology. Applied Engineering, 3, 71-84. 
[98] Ghernaout, D., Elboughdiri, N. and Al Arni, S. (2019) Water Reuse (WR): Dares, Restrictions, and Trends. Applied Engineering, 3, 159-170.

[99] Ghernaout, D., Elboughdiri, N. and Ghareba, S. (2019) Drinking Water Reuse: One-Step Closer to Overpassing the "Yuck Factor". Open Access Library Journal, 6, e5895. https://doi.org/10.4236/oalib.1105895

[100] Ghernaout, D. and Elboughdiri, N. (2019) Mechanistic Insight into Disinfection Using Ferrate (VI). Open Access Library Journal, 6, e5946. https://doi.org/10.4236/oalib.1105946

[101] Ghernaout, D. and Elboughdiri, N. (2019) Water Disinfection: Ferrate (VI) as the Greenest Chemical-A Review. Applied Engineering, 3, 171-180.

[102] Ghernaout, D. and Elboughdiri, N. and Alghamdi, A. (2019) Direct Potable Reuse: The Singapore NEWater Project as a Role Model. Open Access Library Journal, 6, e5980. https://doi.org/10.4236/oalib.1105980

[103] Ghernaout, D. and Elboughdiri, N. (2019) Water Reuse: Emerging Contaminants Elimination-Progress and Trends. Open Access Library Journal, 6, e5981. https://doi.org/10.4236/oalib.1105981

[104] Ghernaout, D. and Elboughdiri, N. (2020) Magnetic Field Application: An Underappreciated Outstanding Technology. Open Access Library Journal, 7, e6000.

[105] Ghernaout, D. and Elboughdiri, N. (2020) Antibiotics Resistance in Water Mediums: Background, Facts, and Trends. Applied Engineering, 4, 1-6.

[106] Ghernaout, D. and Elboughdiri, N. (2020) Removing Antibiotic-Resistant Bacteria (ARB) Carrying Genes (ARGs): Challenges and Future Trends. Open Access Library Journal, 7, e6003. https://doi.org/10.4236/oalib.1106003

[107] Ghernaout, D. and Elboughdiri, N. (2020) Is Not It Time to Stop Using Chlorine for Treating Water? Open Access Library Journal, 7, e6007.

[108] Ghernaout, D. and Elboughdiri, N. (2020) On the Treatment Trains for Municipal Wastewater Reuse for Irrigation. Open Access Library Journal, 7, e6088. https://doi.org/10.4236/oalib.1106088

[109] Ghernaout, D. and Elboughdiri, N. (2020) Should We Forbid the Consumption of Antibiotics to Stop the Spread of Resistances in Nature? Open Access Library Journal, 7, e6138.

[110] Ghernaout, D. and Elboughdiri, N. (2020) $\mathrm{UV}-\mathrm{C} / \mathrm{H}_{2} \mathrm{O}_{2}$ and Sunlight $/ \mathrm{H}_{2} \mathrm{O}_{2}$ in the Core of the Best Available Technologies for Dealing with Present Dares in Domestic Wastewater Reuse. Open Access Library Journal, 7, e6161. https://doi.org/10.4236/oalib.1106161

[111] Ghernaout, D., Elboughdiri, N., Ghareba, S. and Salih, A. (2020) Electrochemical Advanced Oxidation Processes (EAOPs) for Disinfecting Water-Fresh Perspectives. Open Access Library Journal, 7, e6257. https://doi.org/10.4236/oalib.1106257

[112] Ghernaout, D. and Elboughdiri, N. (2020) Towards Enhancing Ozone Diffusion for Water Disinfection -Short Notes. Open Access Library Journal, 7, e6253. https://doi.org/10.4236/oalib.1106253

[113] Ghernaout, D., Elboughdiri, N. Ghareba, S. and Salih, A. (2020) Disinfecting Water with the Carbon Fiber-Based Flow-Through Electrode System (FES): Towards Axial Dispersion and Velocity Profile. Open Access Library Journal, 7, e6238. https://doi.org/10.4236/oalib.1106238

[114] Ghernaout, D. (2017) The Holy Koran Revelation: Iron Is a "Sent Down" Metal. American Journal of Environmental Protection, 6, 101-104.

https://doi.org/10.11648/j.ajep.20170604.14 
[115] Ghernaout, D. and Elboughdiri, N. (2020) Environmental Engineering For Stopping Viruses Pandemics. Open Access Library Journal, 7, e6299.

[116] Ghernaout, D. and Elboughdiri, N. (2020) Disinfecting Water: Plasma Discharge for Removing Coronaviruses. Open Access Library Journal, 7, e6314. https://doi.org/10.4236/oalib.1106314

[117] Ghernaout, D. and Elboughdiri, N. (2020) Solar Treatment in the Core of the New Disinfection Technologies. Chemical Science \& Engineering Research, 2, 6-11.

[118] Ghernaout, D. and Elboughdiri, N. (2020) Vacuum-UV Radiation at $185 \mathrm{~nm}$ for Disinfecting Water. Chemical Science \& Engineering Research, 2, 12-17.

[119] Ghernaout, D. and Elboughdiri, N. (2020) Dealing with Cyanobacteria and Cyanotoxins: Engineering Viewpoints. Open Access Library Journal, 7, e6363.

[120] Kim, M.-K. and Zoh, K.-D. (2016) Occurrence and Their Removal of Micropollutants. Environmental Engineering Research, 21, 319-332.

https://doi.org/10.4491/eer.2016.115 